\title{
The Relationship between the Improvement of Foreign University Leadership and the Modernization of University Governance
}

\author{
Chunyan $\mathrm{He}$ \\ Adamson University, Philippines \\ 2469387394@qq.com
}

\begin{abstract}
Universities are leading, leading, basic, and monopolistic in terms of high-tech knowledge production and productivity transformation, knowledge innovation talents and high-tech research and development talents, which determine that universities have become a national economy. A productivity element with dynamic value that is indispensable for take-off, social progress and its stability and sustainable development. On the basis of discussing "why the modernization of university governance capabilities is so important" and clarifying the "relationship between university leadership and university governance capabilities", the paper starts with "ideological power", "organizational power", "Decision-making power", "institutional power", and "resource power". The 7 aspects of "cultural power" and "principal power" construct and interpret the university leadership element model.
\end{abstract}

Keywords: University Leadership; Modernization of University Governance; Teacher Leadership; Improvement Path.

\section{Introduction}

As a special social organization that integrates multiple functions, relatively independent members, complex organizational structure and power structure, the university is a special social organization. When the external system and resource supply problems required for its own construction and development have been better resolved, The decisive influence on the quality of its development mainly comes from its internal governance, and the key to improving the level of university internal governance is the improvement of the university's internal governance capabilities [1]. In view of the fact that the modernization of national governance system and governance capacity is closely related to the modernization of higher education governance system and governance capacity, especially the university governance system and governance capacity modernization of specific undertakers and implementers of higher education, this research intends to propose and answer "Why is the modernization of university governance so important", "How is the relationship between university leadership and university governance", "How to promote the modernization of university governance to improve university leadership" 3 questions, in order to help universities run schools through the discussion of the above issues The school officials recognize the importance of the modernization of university governance capabilities to a modernized power and make it clear that the improvement of university leadership is a necessary path to promote the modernization of university governance capabilities.

\section{The Importance of University Leadership in School Governance}

Those who run schools and govern schools must realize that in the current process of building first-class universities, the contradiction between competitiveness enhancement and resource embarrassment has begun to transform into the contradiction between competitiveness enhancement and internal governance system backwardness. The competition of first-class universities determines its success or failure within the university. Governance system and governance capabilities. The internal governance of a university is an insurmountable operational basis in the construction of a first-class university, and it plays a key role in the effectiveness of the construction of a first-class 
university. At present, the level of importance and promotion of university governance at the Chinese level is unprecedented. In particular, the "double first-class" university construction plan clearly puts university governance in a very important position. After the external institutional supply and resource input of the university have been greatly improved, how to improve the internal governance of the university has indeed become an important topic at present. There can be no first-class universities without first-class disciplines, but there are no first-class universities only with first-class disciplines [2]. The construction of disciplines and the implementation of disciplines are all within the scope of governance, so first-class governance is necessary for first-class universities Conditions, without first-class governance, there will certainly not be first-class universities.

When talking about the "Belt and Road Initiative", General Secretary Xi Jinping said that we should start from the "freehand brushwork" that outlines the overall layout to the focus on key and meticulous "meticulous paintings", and the same is true for university governance. After the reform and opening up, especially the "National Medium and Long-term Educational Reform and Development Program Outline (2010-2020)" proposed to improve the modern university system with Chinese characteristics, from an objective point of view, our time has been relatively short, and from a subjective point of view our degree of importance Not enough, this is reflected in the internal governance of the university, whether it is at the school level or at the department level, it has not received the attention it deserves.

\section{The Significance of the Modernization of University Governance}

The internal governance structure of the university plays an important role in the exercise of Decision-making power among stakeholders and the allocation of resources in the internal governance process of the university. It has the functions of coordinating interests, improving performance, motivating employees, ensuring academics, and optimizing resources. Although there is no unified model and absolute standard for the improvement of the university's internal governance structure, it should be based on the premise of following the internal laws of the university, focusing on balancing the multiple power relations within the university, and improving the governance ability as the goal.

Due to the leading, leading, basic and monopolistic nature of universities in the production of hightech knowledge and its productivity transformation, knowledge innovation talents and high-tech R\&D talents, universities have become a national economic take-off., Social progress and stability, and the indispensable productivity elements with dynamic value for sustainable development. As a result, in the process of national modernization, the biggest challenge we face is higher education, which is decisive for high-tech knowledge, high-tech and its innovation. Take the lead in modernizing the university. In the context of increasingly fierce international competition, the modernization of the country's higher education has the extremely important importance of placing top priority and seizing opportunities. The high-level officials of the central government have realized that competition between countries is, in the final analysis, university competition with knowledge innovation and personnel training as its core mission. In order to make universities better serve the system and make greater contributions, they have been continuously contributing to the benefit of universities. Run schools according to the rules, educate people, create a good system environment and provide superior resource conditions. In this context, whether a university can improve its international competitiveness in knowledge innovation and talent training depends to a large extent on the efficiency of the university's internal governance [3]. This leads to another conclusion: in the logical chain of national modernization and the modernization of the national governance system (see Figure 1). The modernization of the national governance system must be driven by the modernization of the higher education governance system, and the modernization of the higher education governance system must be based on the modernization of the university governance system. Based on the conclusions obtained from the discussion of the relationship between the governance system and the governance capacity, it is not difficult to obtain the modernization of the university governance 
capacity. It plays a fundamental role in the modernization of the country, that is, the building of a modern and powerful country.
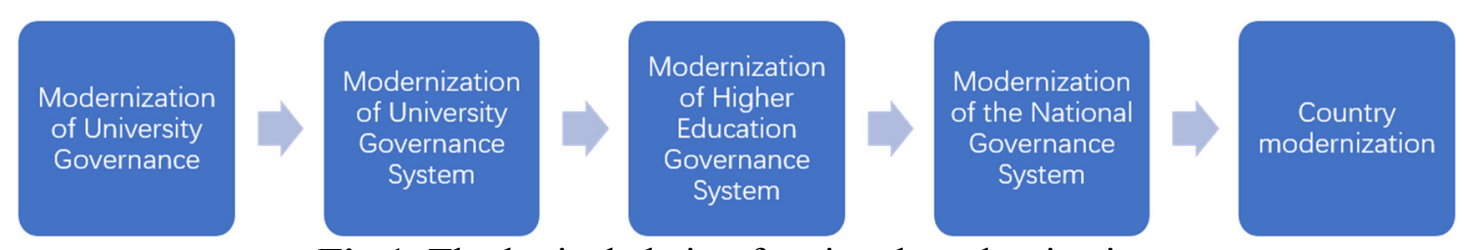

Fig 1. The logical chain of national modernization

\section{The Relationship between University Leadership and Modern Governance Capabilities of Universities and Ways to Improve}

\subsection{Efforts to Improve the Leadership of the Party Committee}

The leadership of the university party committee refers to the ability of the university party committee to lead and unite the school's party members, cadres, and teachers and students to achieve the school's goals in accordance with the requirements of the national education guidelines and policies and the law of higher education's own development. It is the ability of the university party committee to form, The general term for the ability to develop and serve its leadership process. It mainly includes elements such as the planning power, Decision-making power, control power, and cohesion of the party committee, as shown in Figure 2.

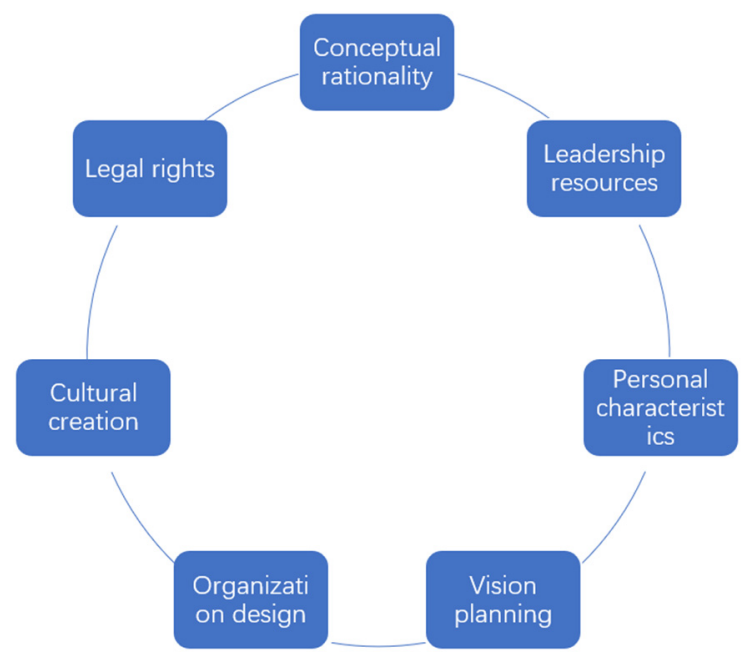

Fig 2. Leadership elements

\subsubsection{Planning}

The planning ability is reflected in the leadership's Decision-making level, reflecting the advancement and predictability of the work. The party committee is the core of leadership of universities and has the leadership responsibilities of grasping the direction, taking over the overall situation, and conspiring together for major issues [4]. It is necessary to take the direction of running a school and plan the development of the school scientifically. Party committees must be good at thinking and properly solving a series of major issues related to the overall, forward-looking and strategic nature of the reform, development and stability of colleges and universities, focusing on solving what kind of university to run, how to run a university, and what kind of people to train and how to train people. Problems, solve the problems of development positioning, development goals and development strategies, and take the promotion of school career development as the starting point and end point of planning all work. Innovation is the soul of a school's development. The party committee of a university must have the ability to innovate quickly and adapt quickly, promote 
various changes with innovative thinking, and plan the development of the university with innovative thinking.

\subsubsection{Decision-making Power}

Decision-making ability refers to the comprehensive ability of leading managers to make decisions, make decisions, and set directions. The Decision-making power of college party committees is embodied in scientific and democratic Decision-making, ensuring the objectivity, scientificity, efficiency and innovation of Decision-making, and reducing policy errors.

\subsubsection{Driving Force}

In order for a university party committee to lead a university well, in addition to enthusiasm, it needs the wisdom to manage complex situations. To formulate and deepen strategic development plans, to condense the development forces of teachers and students, and to promote the sustained, healthy and rapid development of schools is an important manifestation of the ability of college party committees to control.

\subsubsection{Cohesion}

The party committee should play a leading role in rallying the hearts and minds of all teachers, students and staff. Strengthen the construction of grass-roots party organizations, do a good job in the ideological and political work of teachers, students and staff, and provide ideological and organizational guarantees for the reform and development of colleges and universities [5]. Promote the construction of a harmonious campus, coordinate the interests of different groups, strive to make the school's policies and regulations better reflect the interests of teachers, students and employees, and properly handle the relationship between stimulating vitality and forming synergy, thereby enhancing cohesion. Adhere to the strict governance of the party, do a good job in building a clean and honest government, and regularly educate party members and cadres on party conduct and clean government, and improve the ideological, conviction, political discipline, and work style quality of leading cadres at all levels.

\subsection{Efforts to Improve the Management Ability of the Principal}

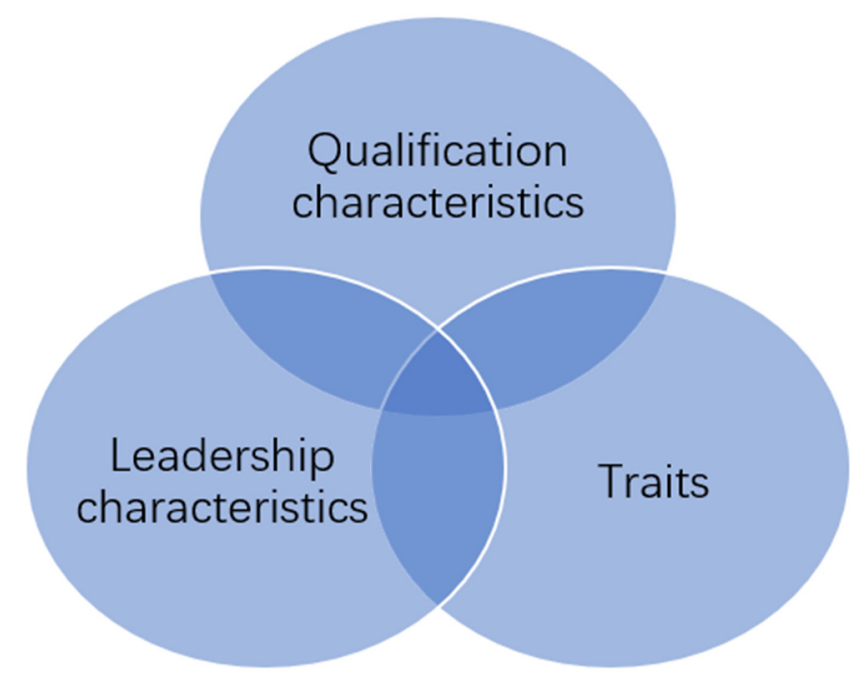

Fig 3. Competency analysis framework of university leaders

The principal is the legal representative of the school, a key figure in leading a university to complete its mission and achieve its goals, and is responsible for running the school. Under the leadership of the school's party committee, the principal implements the party's education policy, organizes the implementation of relevant resolutions of the university's party committee, exercises various functions and powers prescribed by the Higher Education Law, and is fully responsible for teaching, scientific research, and administrative management. The principal's management ability mainly includes thinking ability, innovation ability, internal and external coordination ability, and 
execution ability [6]. In order to explain the competence that university presidents should have, that is, leadership characteristics, the author uses inductive and deductive methods to research and put forward the "University Leadership Competency Analysis Framework" and the "University Organization and the Relationship Analysis Framework of the Competency of the President" (see Figure 3).

\subsubsection{Thinking Ability}

The principal should broaden his horizons, possess scientific strategic thinking, and be full of distinctive educational thoughts and concepts, and be committed to cultivating the university's distinctive school-running characteristics and school-running style.

\subsubsection{Innovation}

The institutional environment of the university has changed, and its function has been continuously developed and changed with the evolution of society. The role of the integration of production, education and research will become more obvious. These urgent needs university presidents can not only follow the requirements of their superiors; nor can they only follow the requirements of the society. The wind is moving. Principals must have strong creativity, implement brand strategies, enhance the school's competitiveness in the market, obtain support in social services, seize development opportunities, achieve win-win cooperation in cooperation, and truly develop their own characteristics.

\subsubsection{Coordination}

The university is a big stage, and the principal is the director on the stage. Only when the scheduling and command are well-directed can the whole school play beautiful notes. Compared with foreign universities, the presidents of universities in my country are more specific, such as discipline construction, teaching quality, scientific research level, etc., and they must be good at dealing with various intricate relationships inside and outside the university. For example, fundraising has now become an important responsibility of the principal [7]. The secret of fundraising is that colleges and universities must learn to actively promote themselves to the society, share the mission and contributions of the school with the public, so as to increase the enthusiasm and initiative of social forces to participate in the development of the university.

\subsubsection{Implementation}

Implementation is the key link of goals and results. The key to improving governance capabilities is to improve execution and implementation capabilities. The principal's executive power is embodied in the pioneering and innovative spirit of "seeking" new ideas, embodied in the courage to take responsibility as "doing" new results, embodied in the truth-seeking and pragmatic style of "struggling" to produce new results . It is necessary to take the lead in implementing the party and government's Decision-making and deployment, taking the lead in the implementation of various tasks, taking the lead in learning politics, economics, management and other work-related knowledge to promote scientific development, taking the lead in strengthening its own style of work, shaping personality charm and improving work implementation.

\subsection{Focus on Improving the Academic Ability of Professors}

The reform of academic organization management and the development of leadership capabilities are fundamentally aimed at advancing and deepening scientific research in universities. In the context of internationalization, international cooperation in scientific research is the most important and highend practice platform for academic leadership building in universities, and an important manifestation of academic leadership building in universities, whether it is for the development of the leader's own ability or for himself and the teachers and students of the organization. The improvement of the quality of the results plays a very important role in promoting.

Specifically, there are three main paths for university scientific research international cooperation in the context of internationalization: First, establish a long-term mechanism for international 
scientific research cooperation. Professor Cornelis, former vice-president of the Dutch-Speaking Brussels Free University (VUB), believes that it is necessary to strengthen the network of international joint scientific research institutions and conduct research on academic and technical topics in various fields to enhance the sustainability of cooperation and the normalization of personnel migration. At the same time, in the practice of international scientific research cooperation, attention should be paid to coordinating and solving the problems of financial support for cooperative projects, the cultivation of the international vision of project leaders, and the development of school technology promotion departments [8]. The second is to establish key research centers to continuously improve scientific research capabilities. Huang Haijun, vice president of Beijing University of Aeronautics and Astronautics, believes that the establishment of national key laboratories, engineering research centers, provincial and ministerial core laboratories, etc., is conducive to building core scientific research forces; based on the characteristics of the school, strive to participate in relevant major national projects in key research fields. It is also one of the effective ways to enhance scientific research strength. The third is to build a team of international scientific research talents in universities. Edalat, the head of the Scientific Research Office of Stockholm University, shared his experience in talent training mode, project leader training and team building in international cooperation. He pointed out that in the construction of international scientific research teams, it is necessary to identify and train core scientific research management personnel with proactive, seeking, cultural adaptability, work competence and other qualities; through international scientific research projects and doctoral courses, etc., gather in school and overseas Top researchers. Huang Haijun, vice president of Beijing University of Aeronautics and Astronautics, also proposed that multi-level and multi-form international cooperation between schools, professors, and students can be used to promote the improvement of the scientific research team. For example, joint research and teaching can be carried out at the teacher level and joint research and teaching can be carried out at the student level. Degree, summer program, intern program, etc.

\subsection{Focus on Improving the Participation of Teachers and Students}

Strengthen the sense of ownership of the faculty and staff, eliminate the employee's thinking of "not in their position and not seeking their own politics", and realize that they are the masters of the school. Strengthen the awareness of democracy and responsibility, realize that participating in democratic management is one's own right and obligation, personal interests are closely related to the overall interests of the school, and have the responsibility to safeguard the interests of the school, and actively contribute to the development and reform of the school. While enhancing their own professional capabilities, they must also focus on the learning of management knowledge, improve their overall quality, and enhance their ability to participate in and discuss politics. The cultivation of the democratic concept of college students lies not only in the guidance and education of the democratic concept, but also in acquiring knowledge and experience in the process of democratic practice. The deeper the individual's participation, the more they have the ability to participate.

\section{Conclusion}

The academic leadership level of a university can be investigated and analyzed from the three dimensions of capacity building, work operation, and result performance. In terms of capacity building, it can be divided into academic organization management reform and academic leadership development. The former is the guarantee and the latter is the center. In terms of work operation, it mainly refers to the central work of academic organizations-the development of scientific research activities; the result level is mainly Refers to the contribution of scientific research results to economic and social development. In terms of the relationship between the three, academic organization management reform and leadership development are important supports for university scientific research operations, and capacity building and work operations jointly determine the quantity and 
quality of scientific research output. This cognitive logic will be of great benefit to thinking about the construction of academic leadership in Chinese universities in the future.

\section{References}

[1] O'sullivan, K. Working together to foster education innovation: The student dimension in university governance. IOSR Journal of Humanities and Social Science (IOSR-JHSS), Vol. 23(2018) No. 6, p.5966.

[2] Guangli, Z. Institutional Logic of University Governance Reform in China. Chinese Education \& Society, Vol. 53(2020) No. 4, p. 163-174.

[3] Subramanian, V. K. (2018). From government to governance: Teach for India and new networks of reform in school education. Contemporary Education Dialogue, Vol. 15(2018) No. 1, p.21-50.

[4] Gornitzka, A., Maassen, P., \& De Boer, H. Change in university governance structures in continental Europe. Higher Education Quarterly, Vol. 71(2017) No. 3, p. 274-289.

[5] Greany, T. Balancing the needs of policy and practice, while remaining authentic: an analysis of leadership and governance in three national school leadership colleges. Cylchgrawn Addysg Cymru/ Wales Journal of Education, Vol. 20(2018) No. 2, p. 63-98.

[6] Quesel, C., Näpfli, J., \& Buser, P. A. Principals' views on civic and parental participation in school governance in Switzerland. Educational Administration Quarterly, Vol. 53(2017) No. 4, p.585-615.

[7] Eacott, S. School leadership and the cult of the guru: the neo-Taylorism of Hattie. School Leadership \& Management, Vol. 37(2017) No. 4, p. 413-426.

[8] Denecker, C. School Principals' Work Stress in an Era of New Education Governance. Swiss Journal of Sociology, Vol. 45(2019) No. 3, p. 447-466. 